\title{
NEAR SURFACE TURBULENCE OCCURRING OVER HETEROGENEOUS TERRAIN AND STABLE CONDITIONS
}

\author{
Luiz E. Medeiros ${ }^{1,2}$, David R. Fitzjarrald ${ }^{1}$ \\ ${ }^{1}$ University at Albany, State University of New York \\ ${ }^{2}$ Universidade Federal de Santa Maria
}

\begin{abstract}
Network averaged surface heat and momentum fluxes of a region with heterogeneous surface are displayed as function of a Richardson number $\left(R i_{b r}\right)$. The results indicate that the need for extra mixing above bulk Richardson number critical (Ricr), in numerical weather prediction models (NWP), is justified experimentally. There is still network flux even when $R i_{b r} \gg R i_{c r}$. The network of surface flux stations shows that there are preferential stations for the occurrence of strong turbulence under same stability conditions of the meso-scale flow.
\end{abstract}

\section{RESUMO}

Fluxos médios de um conjunto de estações localizadas em uma região de superfície heterogênea, são dispostos em função de um número de Richardson regional $\left(R i_{b r}\right)$. O procedimento de se manter turbulência, mesmo quando $R i_{b r}$ se encontra acima de seu valor critico $\left(R i_{c r}\right)$, usado em modelos numéricos de previsão do tempo, é justificado experimentalmente. Os resultados experimentais mostram que a turbulência não cessa mesmo quando $R i_{b r} \gg R i_{c r}$. A rede de estações mostra que existem locais preferências para as transferências de momentum e calor para uma região com superfície heterogênea sob mesmas condições de estabilidade regional.

\section{INTRODUCTION}

The Stable boundary layer (SBL) forms usually during the night over land primarily due the air contact with the cold surface, which is established as consequence of longwave radiation divergence. Turbulence mixes the air near the surface increasing the cooling of the air. NWP models have difficulties on dealing with very stable boundary layer, which happens over land under light winds and clear skies. Under these conditions the turbulence near the surface is intermittent and not spatially continuous (Acevedo and Fitzjarrald 2003, hereafter AF2003). This problem arises because NWPs adopt a classical concept of the SBL, in which there is continuous turbulence close to the ground. In many cases, a first order closure $K$-theory schemes are used to obtain the surface fluxes (McCabe and Brown, 2007). Turbulent diffusion coefficients are usually based on stability functions that depend on a bulk Richardson number (Rib). Different kinds of stability functions are used to adjust the turbulent diffusion coefficients for momentum $K_{m}$ and heat $K_{h}$. In modeling (Delage, 1997), it has been found necessary to allow mixing to occur even for grid-cell with Rib $>1 / 4$ (the critical Richardson number Ricr $=1 / 4)$. In practice, it is done using different types of stability functions. Given ideal surface conditions (e. g. flat surface with homogeneous roughness) bursts of turbulence could plausibly occur randomly across the landscape, however more realistic landscapes have heterogeneous landscapes whose effects should be considered when analyzing near surface turbulence. Thus the objective here is to identify how near surface turbulence is distributed across a heterogeneous landscape, and find out if unphysical extra mixing, necessary to improve the models 
forecast, under very stable conditions (Rib > Ricr) can be attributed to real extra mixing observed at certain parts of the domain.

2. DATA

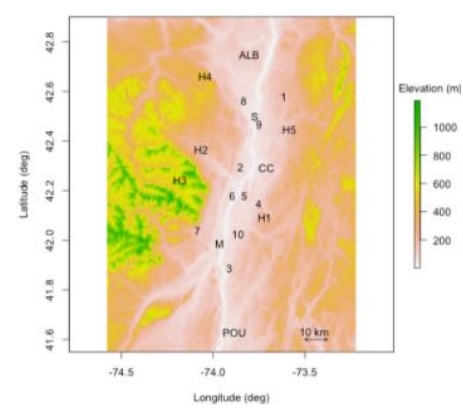

Figure 1: Topography of the HVAMS region. Numbers from 1 to 10 refer to surface flux stations, ALB to soundings and hourly surface weather data, POU to hourly surface weather data, and M to the $915 \mathrm{MHz}$ Doppler radar (wind profiler).

The data used is from the Hudson Valley Ambient Meteorology Study (HVAMS) and corresponds to the period between mid September 2003 and end of October 2003, with a network of ten surface flux stations, one weather station, one aircraft, and one wind profiler (Fig. 1).

\section{RESULTS}

A regional Richardson number $\left(R i_{b r}\right)$, intended to evaluate the stability of the regional flow, was developed based on sounding and surface station data. The network average momentum and sensible heat fluxes have a clear dependence in terms of $R i_{b r}$ for the range $0<R i_{b r}<50$ (Fig. 2). The most notable result is that there is appreciable network average flux when $R i_{b r}>R i_{c r}$. This can justify the practice of allow mixing in models when $R i_{b r}>1 / 4$. It also may illustrate that the $R i_{c r}=1 / 4$ cutoff for turbulence is not suitable for heterogeneous terrain. The shot-tailed stability functions, which do not allow mixing for $R i_{b r}>R i_{c r}$, perform better in weak stable conditions, while longtailed ones (which allow mixing when at supercritical) perform well in strong stability conditions.
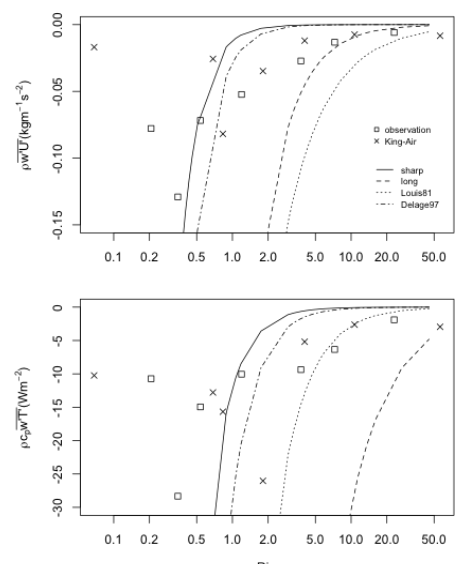

Figure 2. a) Momentum flux as function of $R i_{b r}$. Squares are experimental data, and the various line types are the predicted theoretical momentum using stability functions. Each point represents five nights bin-average of nighttime network flux average. b) Same as in a) but for heat flux. 
Figure 3 shows that under same stability conditions of background flow $\left(R i_{b r}\right)$, the different stations have different momentum and heat exchanges. There are preferential sites for occurrence of mixing. As all stations had different site surface characteristics e. g. exposure, slope, concavity and elevation, this result shows that spatial heterogeneity influences the turbulence activity locally.

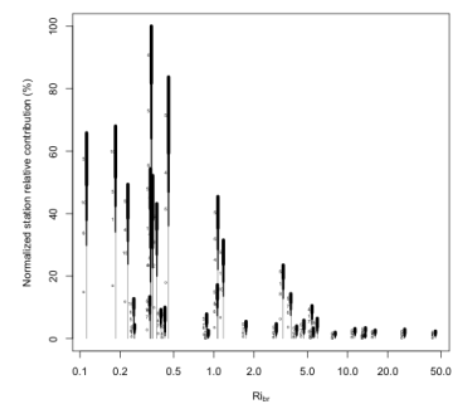

Figure 3 Normalized station relative contribution to the nightly network average momentum flux versus $R i_{b r}$. Total length of the each bar is normalized by the maximum network flux found during period. The widths indicate different stations (thickest $=1^{\text {st }}$ dominant station, $2^{\text {nd }}$ thickest $=2^{\text {nd }}$ dominant station, $2^{\text {nd }}$ thinnest $=3^{\text {rd }}$ dominant station, and thinnest $=$ all other stations) and the length the station's individual contribution.

\section{SUMMARY}

The need for extra mixing above $R i_{c r}$ in NWP models is justified by the experimental results found. There are still network-averaged fluxes in the regime $R i_{b r} \gg R i_{c r}$. Spatial heterogeneity of landscape forces mixing not to be uniform across the landscape. Places like stations 5, 4, 6 and 10 dominate the regional momentum and sensible heat exchanges.

\section{REFERENCES}

Acevedo, O.C. and Fitzjarrald, D.R.: 2003, In the Core of the Night - Effects of Intermittent Mixing on a Horizontally Heterogeneous Surface, Bound-Lay Meteorol, 106, 1-33.

Delage, Y., 1997: Parameterising sub-grid scale vertical transport in atmospheric models under statically stable conditions, Bound-Lay Meteorol, 82, 23 - 48.

McCabe, A., and Brown. A. R.: 2007, The role of Surface Heterogeneity in Modeling the Stable Boundary Layer, Bound-Lay Meteorol, 122, 517 - 534. 